\title{
STRUCTURE OF ANXIETY ASSOCIATED WITH COVID-19 PANDEMIC: THE ONLINE SURVEY RESULTS
}

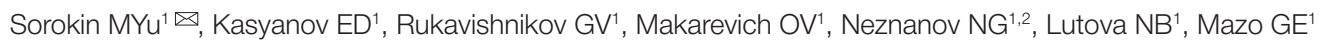

${ }^{1}$ V.M. Bekhterev National Medical Research Center for Psychiatry and Neurology, Saint-Petersburg, Russia

${ }^{2}$ Pavlov First Saint Petersburg State Medical University, Saint-Petersburg, Russia

The COVID-19 pandemic imposed not only serious threats to the physical health of the population, but also provoked a wide range of psychological problems. The study was aimed to define the structure of anxiety in the population during the epidemic period, as well as to identify the most vulnerable social groups (including individuals with affective disorders) which were most in need of psychological and/or psychiatric help. The online survey of 1957 Russian-speaking respondents aged over 18 was carried out from March 30 to April 5, 2020. The anxiety distress level was verified using the Psychological Stress Measure (PSM-25), the stigmatization of individuals experiencing respiratory symptoms was assessed using the modified Perceived Devaluation-Discrimination Questionnaire (PDD; Cronbach's $\alpha=0.707$ ). In $99.8 \%$ of respondents, the combination of various concerns associated with COVID-19 was observed, the mean psychological stress score was increased to moderate level (score $104.9 \pm 34.4$ ), and the stigmatization score exceeded the whole sample median value $(19.5 \pm 3.4 ; \mathrm{Me}=17)$. About $35 \%$ of respondents had concerns associated with anxiety distress (Cohen's $d=0.16-0.39$ ): these were the "risk of social isolation" and the "possible lack of medication for daily use". The following groups of respondents were the most susceptible to the stress: people with affective disorders, young people (aged $\leq 20$ ), unemployed persons, single persons, people with no formal education, and women. Thus, the broad sectors of the population need correction of anxiety distress associated with the COVID-19 pandemic. Therefore, the measures' implementation should be targeted, and in terms of coverage and content oriented to the identified vulnerable social groups.

Keywords: coronavirus infection, pandemic, COVID-19, mental health, anxiety, affective disorders, associated stigma

Acknowledgements: we would like to express our gratitude to the Russian Society of Psychiatrists (RSP) members, to Anastasia Petrova and the Partnership of Equal ANPO, to Maria Pushkina (Favorskaya) and the Bipolar association, to Victor Lebedev and the Pinel's Affair project, and to the Psychiatry \& Neurosciences educational service.

Author contribution: Sorokin MYu — research design, statistical processing and data analysis, manuscript writing; Kasyanov ED — research design, data acquisition and analysis, manuscript writing; Rukavishnikov GV — research design, data analysis, manuscript writing; Makarevich OV — research design, manuscript writing; Neznanov NG — editing; Lutova NB, Mazo GE — research concept and design, data analysis, manuscript writing and editing.

Compliance with ethical standards: the study was performed in accordance with the World Medical Association Declaration of Helsinki (2013). All participants submitted the consent to personal data processing.

$\triangle$ Correspondence should be addressed: Mikhail Yu. Sorokin

Bekhtereva, 3, Saint-Petersburg, 192019; m.sorokin@list

Received: 06.05.2020 Accepted: 21.05.2020 Published online: 02.06.2020

DOI: $10.24075 /$ brsmu.2020.030

\section{СТРУКТУРА ТРЕВОЖНЫХ ПЕРЕЖИВАНИЙ, АССОЦИИРОВАННЫХ С РАСПРОСТРАНЕНИЕМ COVID-19: ДАННЫЕ ОНЛАЙН-ОПРОСА}

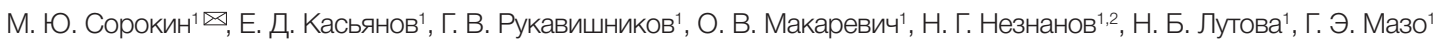

${ }^{1}$ Национальный медицинский исследовательский центр психиатрии и неврологии имени В. М. Бехтерева, Санкт-Петербург, Россия

2 Первый Санкт-Петербургский государственный медицинский университет имени академика И. П. Павлова, Санкт-Петербург, Россия

\begin{abstract}
Пандемия COVID-19 не только создала серьезные угрозы для физического здоровья населения, но и вызвала широкий спектр психологических проблем. Целью работы было выявить структуру тревожных переживаний населения в период эпидемии и определить наиболее уязвимые социальные группы (в том числе среди лиц с аффективными расстройствами), больше всего нуждающиеся в психологической и/или психиатрической помощи. Было проведено онлайн-анкетирование 1957 русскоговорящих респондентов старше 18 лет в период с 30 марта по 5 апреля 2020 г. Уровень тревожного дистресса верифицировали по шкале психологического стресса (PSM-25), стигматизацию лиц с респираторными симптомами по модифицированному опроснику обесценивания/дискриминации (PDD; Cronbach's $\alpha=0,707$ ). У 99,8\% респондентов обнаружено сочетание нескольких типов тревожных переживаний о COVID-19, показатель стресса был повышен до уровня средней интенсивности (104,9 \pm 34,4 балла), а показатель стигматизации превосходил медианное значение по выборке (19,5 \pm 3,4; Ме = 17). До 35\% респондентов имели опасения, ассоциированные с тревожным дистрессом (Cohen's d = 0,16-0,39): «риск изоляции» и «возможное отсутствие лекарств для ежедневного приема». Особенно подверженными психологическому стрессу оказались страдающие аффективными расстройствами, лица молодого возраста ( $\leq 20$ лет), безработные, холостые/незамужние, не имеющие высшего образования и женщины. Таким образом, широкие слои населения нуждаются в коррекции дистрессовых опасений на фоне пандемии COVID-19, поэтому их проведение должно быть адресным, ориентированным по степени охвата и содержанию на выявленные уязвимые социальные группы.
\end{abstract}

Ключевые слова: коронавирусная инфекция, пандемия, COVID-19, психическое здоровье, тревога, аффективные расстройства, ассоциированная стигма

Благодарности: членам Российского общества психиатров, Анастасии Петровой и АНО «Партнерство равных», Марии Фаворской и ассоциации «Биполярники», Виктору Лебедеву и проекту «Дело Пинеля», а также просветительскому порталу «Психиатрия \& Нейронауки».

Вклад авторов: М. Ю. Сорокин - разработка дизайна исследования, статистическая обработка и анализ полученных данных, подготовка текста; Е. Д. Касьянов - разработка дизайна исследования, сбор материала, анализ полученных данных, подготовка текста; Г. В. Рукавишников - разработка дизайна исследования, анализ полученных данных, подготовка текста; О. В. Макаревич - разработка дизайна исследования, подготовка текста; Н. Г. Незнанов - редактирование; Н. Б. Лутова, Г. Э. Мазо - разработка концепции и дизайна исследования, анализ полученных данных, подготовка текста, редактирование.

Соблюдение этических стандартов: исследование проведено в соответствии с Хельсинкской декларацией Всемирной медицинской ассоциации (2013) Все участники дали согласие на обработку персональных данных перед включением в исследование.

$\triangle$ Для корреспонденции: Михаил Юрьевич Сорокин

ул. Бехтерева, д. 3, г. Санкт-Петербург, 192019; m.sorokin@list.ru

Статья получена: 06.05.2020 Статья принята к печати: 21.05.2020 Опубликована онлайн: 02.06.2020

DOI: $10.24075 /$ vrgmu.2020.030 
First cases of a novel coronavirus infection, caused by the SARSCoV-2 coronavirus, (COVID-19 from COrona Vlrus Disease 2019) were detected in November 2019 [1]. The infection spread quickly in Wuhan (the capital of the Chinese province of Hubei), then throughout whole China, and later spread to other countries including the Russian Federation leading to a global public health emergency [2]. As early as March 11, 2020, due to the high prevalence of COVID-19 cases, the World Health Organization $(\mathrm{WHO})$ announced the current situation as a pandemic [3]. First patients with COVID-19 in the Russian Federation were identified on January 31, 2020. In early April, more than 5,000 Russians had confirmed diagnoses [4, 5].

The COVID-19 pandemic imposed serious threats to people's physical health and life. Moreover, the risk of coronavirus infection caused a wide range of psychological problems among the population of countries with a high spread of viral infection, such as panic, anxiety, and depression [6]. Since March 2020, many governments around the world have introduced specific quarantine measures to limit the spread of the virus and minimize the burden on healthcare services. People over 65, individuals with comorbidities and pregnant women were proposed to isolate themselves from direct contact with other people for at least 12 weeks, and the patients suspected of carrying coronavirus together with those living with them were instructed to stay at home and isolate themselves for at least 14 days [7].

Thus, the current situation involves a number of factors significantly affecting the mental health of the population:

1) unprecedented, potentially life-threatening situation of indefinite duration;

2) large-scale quarantine measures in all major cities, which force the residents to stay at home;

3) undefined viral infection incubation period and its possible transmission from asymptomatic patients:

4) reported lack of protective remedies for medical professionals;

5) unstable information background with excess controversial data;

6) uncertainty related to the possible COVID-19 coronavirus infection impact on the economic situation in the country.

According to Chinese researchers, the COVID-19 coronavirus infection pandemic provoked a parallel epidemic of anxiety and depressive reactions [8, 9]. Moreover, certain sectors of the population may be more vulnerable to psychological stress associated with the disease. This is especially true for individuals with affective disorders who are more susceptible to the COVID-19 pandemic related emotional responses, which could manifest in mental symptoms relapses or worsening. This is due to such patients' high sensitivity to stress compared to the general population, and also due to the scheduled psychiatric outpatient appointment limitations. Furthermore, in addition to stress level escalation among the population, stigmatization and discrimination against certain sectors of the population increase [10], even with no evidence of increased morbidity risks in the discriminated groups.

The study was aimed to reveal the structure of anxiety in the population during the epidemic period, as well as to identify the most vulnerable social groups (including individuals with affective disorders) which were most in need of psychological and/or psychiatric help.

\section{METHODS}

\section{Data acquisition}

The data was acquired using the online survey which was carried out from March 30 to April 5, 2020. The participants were proposed to complete the Questionnaire via the Google Forms online platform, which on average took about 15 minutes. The Questionnaire was distributed through social media, as well as via websites of public organizations and communities of interest (see Acknowlegements).

Inclusion criteria: skill of reading in Russian, submitted consent to personal data processing (completion of all proposed Questionnaire forms was considered a consent). Exclusion criteria (defined as freely as possible in order to represent as many social groups as possible among the respondents): 1) age <18; 2) blank sections in the Questionnaire.

The Questionnaire included social and demographic information about the respondents, as well as the information on the presence or absence of affective disorders (major depressive disorder, bipolar affective disorder, generalized anxiety disorder, cyclothymia, dysthymia) and somatic pathology.

The participants were proposed to mark any amount of 10 Questionnaire paragraphs describing various types of concerns associated with the COVID-19 pandemic, as well as any amount of 6 behavioral patterns of infection prevention (for the Questionnaire full version see Appendix). Furthermore, the respondents could determine how often they requested information about a pandemic during the last week in the range from "never' to "every hour" (according to the 8-point scale). Questions from the Psychological Stress Measure (PSM-25) were used for the anxiety distress assessment [11]. Based on the widely used Perceived Stigmatization Questionnaire (Devaluation-Discrimination section, PDD) [12], the statements

Table 1. Social and demographic features correlation with psychological and behavioral responses related to COVID-19

\begin{tabular}{|c|c|c|c|c|c|}
\hline & $\begin{array}{l}\text { Information about } \\
\text { COVID-19 search } \\
\text { frequency }\end{array}$ & $\begin{array}{l}\text { Number of concern } \\
\text { themes associated } \\
\text { with COVID-19 }\end{array}$ & $\begin{array}{c}\text { Number of COVID-19 } \\
\text { infection prevention measures }\end{array}$ & Stress (PSM-25) & Stigmatization \\
\hline Age & $0.06^{\star \star \star}$ & $-0.23^{\star \star *}$ & - & $-0.38^{\star \star *}$ & $0.06^{\star *}$ \\
\hline Education & $0.08^{\star \star \star}$ & $-0.15^{\star \star \star}$ & - & $-0.22^{\star \star \star}$ & - \\
\hline $\begin{array}{l}\text { Information about COVID-19 } \\
\text { search frequency }\end{array}$ & 1.000 & - & - & - & - \\
\hline $\begin{array}{l}\text { Number of concern themes } \\
\text { associated with COVID-19 }\end{array}$ & $0.22^{\star \star \star}$ & 1.000 & - & - & - \\
\hline $\begin{array}{l}\text { Number of COVID-19 } \\
\text { infection prevention measures }\end{array}$ & $0.17^{\star \star \star}$ & $0.30^{\star \star \star}$ & 1.000 & - & - \\
\hline Stress (PSM-25) & $0.14^{\star \star \star}$ & $0.28^{\star \star \star}$ & $0.05^{*}$ & 1.000 & - \\
\hline Stigmatization & $0.10^{\star \star \star}$ & $0.12^{\star \star \star}$ & $0.12^{\star \star \star}$ & - & 1.000 \\
\hline
\end{tabular}

Note: Spearman's rank correlation coefficients; $N=1957 ;{ }^{\star} p \leq 0.05 ;{ }^{* \star} p \leq 0.01 ;{ }^{* \star *} p \leq .001$. 
were formulated describing the negative perception of people with the signs of cold (coughing, runny nose, sneezing). The levels of agreement with the Questionnaire statements were evaluated using the 4-point Likert scale. The higher total scores corresponded to more severe stigma intensity.

\section{Statistical analysis}

Statistical data processing was carried out using the SPSS-16 software package (SPSS Inc.; USA). The descriptive statistics were used. Distribution normality test was performed using the skewness and kurtosis calculation. Dispersion for nominal scales was analyzed using the Pearson's $\chi^{2}$ test, and the data for ordinal scales were obtained using the Mann-Whitney U-test. Effect sizes obtained using the Cohen's d and Cramer's $\checkmark$ measures were calculated for groups, the differences between which had the significance level $p \leq 0.05$. When comparing the nominal data with more than two gradations, the interpretation of the effect size was carried out adjusted for the number of degrees of freedom and indicator threshold values for a weak/moderate/strong effect. Spearman's rank correlation coefficients were calculated. The original stigmatization Questionnaire internal consistency assessment was performed using the Cronbach's $\alpha$.

\section{RESULTS}

The final register included 2117 records obtained during the 1st week of the self-isolation regime recommended in Russia (from March 30 to April 5). The data of 160 respondents were excluded from analysis due to age. Thus, the statistical analysis of the 1957 respondents' data was carried out.

\section{Demographics}

Among the participants women prevailed (1649 people, 84.3\%). The average age of the respondents was $31\left(\mathrm{Me}=27 ; \mathrm{Q}_{25}=22\right.$, $Q_{75}=38$ ). The sample included people living in the cities of federal importance (Saint-Petersburg, 21.1\%, Moscow, 16.8\%), all federal districts of Russian Federation (57.6\%), and abroad (4.5\%).

\section{Social characteristics}

About a half of all respondents had a university degree (55.3\%). The $25.6 \%$ of participants reported on the incomplete higher education. The majority of respondents were employed in private (23.6\%) and public (32.2\%) organizations. The medical professionals made up $10.3 \%$ of the sample. The $22.2 \%$ of participants had no permanent employment. The $51.8 \%$ of the sample were single. The $26.9 \%$ of respondents were officially married, and the $12.4 \%$ lived in the de facto marriage.

\section{Comorbidities}

The $54.8 \%$ of respondents reported on the concominant somatic pathology. The $29.5 \%$ of participants confirmed they were diagnosed with affective disorders. Most often the participants mentioned major depressive and bipolar affective disorders (19.8\%), and less frequently the anxiety disorders (6.0\%), cyclothymia or dysthymia (3.7\%).

\section{Characteristics of the participants' psychological and behavioral responses}

Correlation analysis of the whole data set demonstrated that adaptation that adaptation to new living conditions during the COVID-19 spread was a multi-level process with a complex structure of interrelated factors. The higher number of strategies used for coronavirus infection prevention (4 on average: $M e=4 ; Q_{25}=3, Q_{75}=4$ ) and the more frequent search for the epidemic information (twice a day on average: $\mathrm{Me}=6 ; \mathrm{Q}_{25}=5, \mathrm{Q}_{75}=7$ ) correlated in a predictable way. These were associated with the respondents' psychological reactions to the pandemic intensification: the number of anxious concerns about COVID-19 increased, as well as the associated psychological stress level and the tendency to stigmatize people with respiratory symptoms. Almost all of the mentioned above characteristics were also sensitive to the social and demographic parameters of the sample (Table 1).

The $99.8 \%$ of the study participants reported at least two coronavirus related concern themes, and the most common themes number was $5\left(\mathrm{Me}=5 ; \mathrm{Q}_{25}=4, \mathrm{Q}_{75}=6\right.$ ) (Table 2). The anxiety responses diversity was associated with the psychological stress measure (PSM-25) reaching the moderate level of 104.9 in the whole sample $\left(\mathrm{Me}=106 ; \mathrm{Q}_{25}=80\right.$, $Q_{75}=130$ ). Qualitative analysis of the relationship between the specific COVID-19 associated concern themes and the psychological stress and people with respiratory symptoms stigmatization/discrimination levels revealed the multidirectional effects of specific concerns.

The concern about the threat to the life and health of relatives was not associated with significant stress level or stigmatization increase. Possibly, it was due to the maximum

Table 2. Types of COVID-19 related concern themes and corresponding levels of anxiety distress and people with respiratory symptoms stigmatization

\begin{tabular}{|c|c|c|c|}
\hline \multirow{2}{*}{ Concern type } & \multirow{2}{*}{ Prevalence (people/\%) } & \multicolumn{2}{|c|}{ Indicators change (SE): } \\
\hline & & stress & stigma \\
\hline Threat to the life and health of relatives and important people & $1527 / 77.2$ & $-{ }^{*}$ & +0.06 \\
\hline Possible financial difficulties & $1128 / 57.0$ & +0.16 & -0.04 \\
\hline Harsh social consequences & $980 / 49.5$ & +0.14 & -0.08 \\
\hline Lack of specific treatment for COVID-19 & $789 / 39.9$ & +0.1 & +0.19 \\
\hline Disrupted normal routine & $766 / 38.7$ & +0.17 & -0.16 \\
\hline Virus transmissibility & $708 / 35.8$ & +0.1 & +0.27 \\
\hline Threat to the own life & $619 / 31.3$ & +0.14 & +0.36 \\
\hline Lack of commercially available protection remedies & $544 / 27.5$ & +0.16 & +0.23 \\
\hline Possible lack of medication for daily use & $434 / 21.9$ & +0.39 & +0.19 \\
\hline Risk of social isolation & $351 / 17.7$ & +0.43 & -0.14 \\
\hline
\end{tabular}

Note: effect size (SE) is considered weak when $0.2 \leq$ Cohen's $d \leq 0.49 ; p \leq 0.05$. 
Table 3. Anxiety experience features depending on the respondents' health group

\begin{tabular}{|c|c|c|c|c|c|c|}
\hline \multirow{2}{*}{\multicolumn{2}{|c|}{$\begin{array}{l}\text { Concern themes associated } \\
\text { with COVID-19 }\end{array}$}} & \multirow{3}{*}{$\begin{array}{l}\text { Healthy people } \\
\qquad \begin{array}{c}n=643 \\
11.0 \%\end{array}\end{array}$} & \multicolumn{3}{|c|}{ Disorders } & \multirow{4}{*}{$\begin{array}{l}\text { Significance level } \\
\begin{array}{c}x^{2}=63.8 ; p=0.000 \\
\text { SE }=0.25\end{array}\end{array}$} \\
\hline & & & \multirow{2}{*}{$\begin{array}{c}\text { Affective disorders } \\
n=242 \\
21.5 \%\end{array}$} & \multirow{2}{*}{$\begin{array}{c}\text { Somatic disorders } \\
n=737 \\
17.9 \%\end{array}$} & \multirow{2}{*}{$\begin{array}{c}\text { Comorbidities } \\
n=336\end{array}$} & \\
\hline Risk of social & + & & & & & \\
\hline isolation & - & $89.0 \%$ & $78.5 \%$ & $82.1 \%$ & $69.0 \%$ & \\
\hline \multirow{2}{*}{$\begin{array}{l}\text { Lack of medication } \\
\text { for daily use }\end{array}$} & + & $22.2 \%$ & $34.3 \%$ & $14.4 \%$ & $30.4 \%$ & \multirow{2}{*}{$\begin{array}{c}x^{2}=59.6 ; p=0.000 \\
\mathrm{SE}=0.21\end{array}$} \\
\hline & - & $77.8 \%$ & $65.7 \%$ & $85.6 \%$ & $69.6 \%$ & \\
\hline
\end{tabular}

Note: effect size (SE) is considered medium when $0.17 \leq$ Cramers's $V \leq 0.29$.

experience prevalence in the vast majority of respondents. At the same time, the clinically significant psychological stress increase (weak in magnitude) was associated with the two (of 10) most rare concern themes: the "possible lack of medication for daily use" and the "risk of social isolation" (Table 2). In total, 688 study participants (35\% of the sample) reported experiencing at least one of those concerns.

The average total score for the Questionnaire on the people with respiratory symptoms stigmatization was 19.5, with $\mathrm{Me}=17\left(\mathrm{Q}_{25}=15, \mathrm{Q}_{75}=19\right)$ and sufficient internal consistency of the instrument (Cronbach's $\alpha=0.707$ ). The "risk of social isolation" was associated with a significant decrease in the respondents' tendency to stigmatize people with respiratory symptoms. However, the stigmatization increase effects became practically significant only in people with the "virus transmissibility", "threat to the own life" and "lack of commercially available protection remedies" concerns.

\section{Psychological reactions of specific sectors of the population}

Among the groups of respondents, the specific concern themes had some features. Two themes most closely related with psychological stress were observed in participants who had reported being diagnosed with affective disorders (Table 3). Moreover, the "risk of social isolation" caused apprehension mostly in individuals with comorbid affective and somatic disorders. At the same time, the "lack of medication for daily use" concern theme was more frequently reported by participants with affective disorders and no comorbidities.

It is important to note, that among 688 participants reporting at least one of the two main psychological stress associated concern themes, the respondents without mental disorders were as common as those with affective disorders. Unexpectedly, the external validity of the online Questionnaire was confirmed by the prevalence of the specific for people with anxiety disorders fear for their security, which distinguished them from people with mood disorders (Table 4).
In addition to traditional sectors of the population considered most vulnerable to anxiety reactions (patients with affective and somatic disorders) many other cohorts demonstrated various prevailing concerns about COVID-19. Thus, women were worried about the lack of commercially available protection remedies and threat to their own life more often than men (Table 4). Single people, as well as the unemployed and public institutions employees were more likely to be aware of social isolation (Table 5).

In respondents with higher education and academic degrees, as well as in people over 31, the concerns about the risk of social isolation were significantly fewer. A group of participants over 60 tended to be the most wary of financial difficulties the possibly caused by pandemic (Table 6).

\section{DISCUSSION}

The data coming from the online survey made it possible to assess the structure of psychological experience characteristic for Russian-speaking respondents during the first week of the proposed self-isolation regime in Russia. The analysis demonstrated high prevalence of various COVID-19 pandemic associated anxiety trends among the study participants, which cumulatively increased the total psychological stress level in the surveyed sample.

Amidst the changing due to quarantine measures living conditions and routine, various COVID-19 pandemic related concerns predictably arose in the respondents. It is essential to note that concerns about the "threat to the life and health of relatives and important people" did not lead to the psychological stress level increase. Therefore, those could be considered adaptive personality and psychological reactions. At the same time, the concern themes number expansion led to the breakdown of adaptive mechanisms, provoking both the intensification of psychological (higher anxiety) and social stress. The social stress was consciously or unconsciously projected outside, causing the increased stigma. It is important

Table 4. Anxiety experience features depending on the affective disorder type and gender

\begin{tabular}{|c|c|c|c|c|}
\hline \multicolumn{2}{|l|}{ Concern themes associated with COVID-19 } & \multicolumn{2}{|c|}{ Representation by groups } & Significance level \\
\hline \multicolumn{5}{|c|}{ Gender: 1 - men, 2 - women } \\
\hline \multirow{2}{*}{ Lack of protective remedies } & + & $20.1 \%$ & $29.2 \%$ & \multirow{2}{*}{$\begin{array}{c}x^{2}=10.7 ; p=0.001 \\
\mathrm{SE}=0.14\end{array}$} \\
\hline & - & $79.9 \%$ & $70.8 \%$ & \\
\hline \multirow{2}{*}{ Threat to the own life } & + & $23.1 \%$ & $33.2 \%$ & \multirow{2}{*}{$\begin{array}{c}x^{2}=12.4 ; p=0.000 \\
\mathrm{SE}=0.14\end{array}$} \\
\hline & - & $76.9 \%$ & $66.8 \%$ & \\
\hline \multicolumn{5}{|c|}{ Affective disorder type: $1-$ mood disorder, $2-$ anxiety disorder } \\
\hline \multirow{2}{*}{ Threat to the own life } & + & $26.7 \%$ & $40.7 \%$ & \multirow{2}{*}{$\begin{array}{c}x^{2}=8.8 ; p=0.003 \\
\mathrm{SE}=0.12\end{array}$} \\
\hline & - & $73.3 \%$ & $59.3 \%$ & \\
\hline
\end{tabular}

Note: effect size (SE) is considered weak when $0.1 \leq$ Cramers's $V \leq 0.3$. 
Table 5. Anxiety experience features depending on the occupation and marital status

\begin{tabular}{|c|c|c|c|c|c|c|c|}
\hline \multirow{2}{*}{\multicolumn{2}{|c|}{$\begin{array}{l}\text { Concern themes } \\
\text { associated with } \\
\text { COVID-19 }\end{array}$}} & \multicolumn{5}{|c|}{ Representation by groups: } & \multirow{2}{*}{ Significance level } \\
\hline & & 1 & 2 & 3 & 4 & 5 & \\
\hline \multicolumn{8}{|c|}{$\begin{array}{c}\text { Occupation: } 1 \text { - student, } n=271 ; 2-\text { unemployed, } n=435 ; 3-\text { private sector employee, } n=462 ; 4-\text { public sector employee, } n=631 \text {; } \\
5-\text { businessman, } n=158\end{array}$} \\
\hline \multirow{2}{*}{$\begin{array}{l}\text { Risk of social } \\
\text { isolation }\end{array}$} & + & $19.6 \%$ & $25.1 \%$ & $8.2 \%$ & $20.9 \%$ & $12.0 \%$ & \multirow{2}{*}{$\begin{array}{c}x^{2}=52.6 ; p=0.000 \\
\text { SE }=0.19\end{array}$} \\
\hline & - & $80.4 \%$ & $74.9 \%$ & $92.8 \%$ & $79.1 \%$ & $88.0 \%$ & \\
\hline \multicolumn{8}{|c|}{ Marital status: 1 - widowers/widows, $n=30 ; 2-$ divorced, $n=144 ; 3-$ single, $n=1014 ; 4-$ de facto marriage, $n=243 ; 5-$ registered marriage, $n=52$} \\
\hline \multirow{2}{*}{$\begin{array}{l}\text { Risk of social } \\
\text { isolation }\end{array}$} & + & $3.3 \%$ & $13.2 \%$ & $22.5 \%$ & $16.9 \%$ & $11.8 \%$ & \multirow{2}{*}{$\begin{array}{c}x^{2}=34.5 ; p=0.000 \\
\mathrm{SE}=0.16\end{array}$} \\
\hline & - & $96.7 \%$ & $86.8 \%$ & $77.5 \%$ & $83.1 \%$ & $88.2 \%$ & \\
\hline
\end{tabular}

Note: effect size (SE) is considered medium when $0.15 \leq$ Cramers's $V \leq 0.25$.

that psychological stress escalated notably amid the "possible lack of medications for daily use" and the "risk of social isolation" concerns. The first could be due to the subjective perception deterioration, and the second due to quarantine measures provoking a wave of anxiety and anger itself. The stigmatization attitudes increase turned out to be related mostly with the following experiences: "threat to one's own life", "virus transmissibility", and "lack of commercially available protection remedies", which were, to a greater extent, caused by the feeling of loss of control over the situation.

Noteworthy was the data obtained from respondents who reported being diagnosed with affective disorders. For them, as well as for individuals who had not reported any mental disorders, the same types of categories most closely related with psychological stress were common: the "risk of social isolation" and "lack of medications for daily use". However, the participants with comorbid affective and somatic disorders were more wary of "social isolation". At the same time, the "possible lack of medication for daily use" often worried respondents with affective disorders and no somatic comorbidities. Moreover, in people with anxiety disorders compared to participants with affective disorders, the prevalence of a specific "threat to their own life" concern was observed, which emphasized the clinical diversity of their experience.

The obtained data on the respondents' anxious experience structure make it possible to distinguish the features of different sectors of population, which is important for the further design of differentiated psychological and social assistance programs. In particular, the "risk of social isolation" concerns are most common in young respondents (under 31), single people, individuals with no formal education and the unemployed, as well as in people with comorbid affective and somatic disorders. In the first three social groups this may be due to personal immaturity, unformed self-control and self-employment skills, as well as to temporary loss of the ability to communicate. In the unemployed people, the main reason is the financial support reduction. In the older age group the "financial difficulties" become a specific concern theme, which obviously calls for different informational and social interventions.

The WHO COVID-19 Strategic Preparedness and Response Plan includes no strategies addressed the emerging mental health needs [13]. Although, the need for such strategies is likely to increase both during the epidemic and after it.

There are no literature data on psychological reactions at the initial stages of the epidemiological situation deterioration and the quarantine announcement (the official epidemiological distress increase endorsement). In China, which was the first to deal with the medical care organization in order to limit the spread of coronavirus, the Principle for Supporting Mental Wellbeing was developed. The Principle included the following: 1) determining the current status of mental health in the population; 2) determining the group of people at high risk of suicide and aggression; 3) developing the structured assistance measures [14]. However, the psychological assistance effectiveness in the region was considered insufficient, which was due to the lack of experience in teaching the mental health maintenance principles [15].

Thus, the size and social heterogeneity of the risk group require the use of broader social interventions to overcome the pandemic social and psychological consequences. The interventions which may be implemented in accordance with the aid separation principle should include the following: psychosocial support stage, specialized psychological assistance, and clinical and psychological assistance involving psychiatrists. Based on the Chinese experience of psychological assistance arrangement, as well as our data, stigmatization/ discrimination may be one of the barriers making it impossible to establish the effective population assistance service [16].

Table 6. Anxiety experience features depending on the education and age

\begin{tabular}{|c|c|c|c|c|c|c|c|c|}
\hline \multirow{2}{*}{\multicolumn{2}{|c|}{$\begin{array}{l}\text { Concern themes } \\
\text { associated with } \\
\text { COVID-19 }\end{array}$}} & \multicolumn{6}{|c|}{ Representation by groups } & \multirow{2}{*}{ Significance level } \\
\hline & & 1 & 2 & 3 & 4 & 5 & 6 & \\
\hline \multicolumn{9}{|c|}{$\begin{array}{c}\text { Education: } 1-\text { incomplete secondary, } n=31 ; 2-\text { secondary, } n=98 ; 3-\text { professional, } n=164 ; 4-\text { incomplete higher, } n=501 ; 5-\text { higher, } n=1082 \\
6-\text { academic degree, } n=81\end{array}$} \\
\hline \multirow{2}{*}{$\begin{array}{l}\text { Risk of social } \\
\text { isolation }\end{array}$} & + & $25.8 \%$ & $24.5 \%$ & $22.6 \%$ & $24.0 \%$ & $14.5 \%$ & $6.2 \%$ & \multirow{2}{*}{$\begin{array}{c}x^{2}=35.1 ; p=0.000 \\
\mathrm{SE}=0.14\end{array}$} \\
\hline & - & $74.2 \%$ & $75.5 \%$ & $77.4 \%$ & $76.0 \%$ & $82.5 \%$ & $93.8 \%$ & \\
\hline \multicolumn{9}{|c|}{ Age: $1-18-20$ years, $n=310 ; 2-21-30$ years, $n=859 ; 3-31-40$ years, $n=363 ; 4-41-50$ years, $n=231 ; 5-51-60$ years, $n=136 ; 6-60-78$ years, $n=58$} \\
\hline \multirow{2}{*}{$\begin{array}{l}\text { Risk of social } \\
\text { isolation }\end{array}$} & + & $28.7 \%$ & $20.0 \%$ & $14.3 \%$ & $8.2 \%$ & $8.8 \%$ & $12.1 \%$ & \multirow{2}{*}{$\begin{array}{c}x^{2}=54.0 ; p=0.000 \\
\mathrm{SE}=0.18\end{array}$} \\
\hline & - & $71.3 \%$ & $80.0 \%$ & $85.7 \%$ & $91.8 \%$ & $91.2 \%$ & $87.9 \%$ & \\
\hline \multirow{2}{*}{$\begin{array}{l}\text { Financial } \\
\text { difficulties }\end{array}$} & + & $31.3 \%$ & $32.2 \%$ & $30.6 \%$ & $29.9 \%$ & $30.9 \%$ & $39.7 \%$ & \multirow{2}{*}{$\begin{array}{c}x^{2}=101.6 ; p=0.000 \\
\mathrm{SE}=0.13\end{array}$} \\
\hline & - & $68.7 \%$ & $67.8 \%$ & $69.4 \%$ & $70.1 \%$ & $69.1 \%$ & $60.3 \%$ & \\
\hline
\end{tabular}

Note: effect size (SE) is considered medium when $0.13 \leq$ Cramers's $V \leq 0.22$. 
Study limitations. The study results were obtained using the respondents' reports. Although the reports' correlation with the objective experimental psychology test results is usually quite high, the additional profiles verification via expert assessment performed by the researcher may lead to corroboration increase. At the same time, the cross-cutting evaluation would significantly limit the sample size and participation of various sectors of the population (including through experiences of stigma of respondents with affective disorders), as well as scale the period of the first results acquisition. Furthermore, in the context of strongly recommended physical distancing the possibility of face-to-face counseling involving the visit to the clinic is extremely limited. Besides, the rates of epidemic process development and the population psychological response to the COVID-19 pandemic determine the importance of the research promptness and psychological and psychiatric assistance recommendations statement based on the research results.

It is worth noting, that the revealed strength of correlations between the population psychological reactions, applied infection prevention measures and the frequency of searching for information about the pandemic corresponded only to the weak or moderate level of signs association. The described above situation is quite typical for the human psychology studies. On the one hand, this illustrates the inadmissibility of interpreting the correlation as causal even in the context of the study (when the observed features are semantically closely related). On the other hand, the revealed relationships' strength emphasizes the behavior regulation multidimensional nature, when none of the parameters can be considered determinative.

\section{CONCLUSION}

Psychological crisis intervention should be considered an important part of a public health response to the COVID-19 outbreak. The greater involvement of competent specialists in infectious diseases, epidemiology and mental health by the mass media in order to inform the citizens about the effective infection and psychological stress increase prevention measures as opposed to flooding the Internet unprofessional judgments should become the first step. Moreover, the obtained results make it possible to recommend the broader but more precise correction of distress concerns. Additional attention should be paid not only to patients with affective disorders, but also to young people, women, people with no formal education, out-of-work and out-of-school people, and single individuals. The most urgent need for the COVID-19 pandemic anxiety correction was revealed in people aware of the possible lack of medication for daily use and the risk of social isolation, since these types of experience are related to the maximum anxiety distress escalation in the surveyed sample. The access to individual online psychological counseling establishment for general public at the state level, as well as the arrangement of psychological and psychiatric assistance for people in need providing the adequate epidemiological safety, are extremely important, since the psychological stability contributes to the population physical health maintenance.

\section{References}

1. Chan JF-W, Yuan S, Kok KH, To KKW, Chu H, Yang J, et al. A familial cluster of pneumonia associated with the 2019 nove coronavirus indicating person-to-person transmission: a study of a family cluster. The Lancet. 2020; 395 (10223): 514-23. Available from: https://doi.org/10.1016/S0140-6736(20)30154-9.

2. Statement on the second meeting of the International Health Regulations (2005) Emergency Committee regarding the outbreak of novel coronavirus (2019-nCoV). World Health Organization (WHO), 2020. Available from (assessed Feb 15, 2020): https:// www.who.int/news-room/detail/30-01-2020-statement-onthe-second-meeting-of-the-international-health-regulations(2005)-emergency-committee-regarding-the-outbreak-of-novelcoronavirus-(2019-ncov).

3. "WHO Director-General's opening remarks at the media briefing on COVID-19". World Health Organization (WHO) (Press release), 11 March 2020. Archived from the original on 11 March 2020 Available from: https://www.who.int/dg/speeches/detail/whodirector-general-s-opening-remarks-at-the-media-briefing-oncovid-19---11-march-202.

4. V Rossii vyyavili dvuh pervyh bol'nyh koronavirusom. Available from: https://www.interfax.ru/russia/693554. Russian.

5. COVID-19 Dashboard by the Center for Systems Science and Engineering (CSSE) at Johns Hopkins University (JHU). Available from: https://gisanddata.maps.arcgis.com/apps/opsdashboard/ index.html\#/bda7594740fd40299423467b48e9ecf6.

6. Qiu J, Shen B, Zhao M, et al A nationwide survey of psychological distress among Chinese people in the COVID-19 epidemic: implications and policy recommendations. General Psychiatry. 2020; 33: e100213.

7. Brooks SK, Webster RK, Smith LE, Woodland L, Wessely S, Greenberg N, et al. The Psychological Impact of Quarantine and How To Reduce It: Rapid Review of the Evidence. The Lancet. 2020; 395 (10227): 912-20. Available from: https://doi.
org/10.1016/S0140-6736(20)30460-8.

8. Yao H, Chen JH, Xu YF. Patients with mental health disorders in the COVID-19 epidemic. Lancet Psychiatry. 2020; 7 (4): e21. DOI: 10.1016/S2215-0366(20)30090-0/.

9. Lai J, Ma S, Wang Y, Cai Z, Hu J, Wei N, et al. Factors Associated With Mental Health Outcomes Among Health Care Workers Exposed to Coronavirus Disease 2019. JAMA Netw Open. 2020; 3 (3): e203976. DOI: 10.1001/jamanetworkopen.2020.3976.

10. Addressing Stigma. Centers for disease control and prevention. Available from: https://emergency.cdc.gov/cerc/cerccorner/ article_123016.asp.

11. Vodopjanova NE. Psihodiagnostika stressa. SPb.: Piter, 2009; $336 \mathrm{~s}$. Russian.

12. Link B, Cullen F, Frank J, Wozniak J. The Social Rejection of Former Mental Patients: Understanding Why Labels Matter. American Journal of Sociology. 1987; 92 (6): 1461-500. Retrieved April 12, 2020. Available from: www.jstor.org/stable/2779844.

13. Novel coronavirus (2019-nCoV): strategic preparedness and response plan Feb 3, 2020. World Health Organization, 2019 [cited 2020 Feb 7]. Available from: https://www.who.int/docs/ default-source/coronaviruse/srp-04022020.pdf.

14. Li W, Yang Y, Liu ZH, Zhao Y-J, Zhang Q, Zhang L, et al. Progression of Mental Health Services during the COVID-19 Outbreak in China. Int J Biol Sci. 2020; 16 (10): 1732-8. DOI: 10.7150/ijbs.45120.

15. Chen Q, Liang M, Li Y, Cuo J, Fei D, Wang L, et al. Mental health care for medical staff in China during the COVID-19 outbreak. Lancet Psychiatry. 2020; 7 (4): e15-e16. DOI: 10.1016/S22150366(20)30078-X.

16. Kang L, Li Y, Hu S, Chen M, Yang C, Yang BX, et al. The mental health of medical workers in Wuhan, China dealing with the 2019 novel coronavirus. Lancet Psychiatry. 2020; 7 (3): e14. DOl: 10.1016/S2215-0366(20)30047-X. 


\section{Литература}

1. Chan JF-W, Yuan S, Kok KH, To KKW, Chu H, Yang J, et al. A familial cluster of pneumonia associated with the 2019 novel coronavirus indicating person-to-person transmission: a study of a family cluster. The Lancet. 2020; 395 (10223): 514-23. Available from: https://doi.org/10.1016/S0140-6736(20)30154-9.

2. Statement on the second meeting of the International Health Regulations (2005) Emergency Committee regarding the outbreak of novel coronavirus (2019-nCoV). World Health Organization (WHO), 2020. Available from (assessed Feb 15, 2020): https:// www.who.int/news-room/detail/30-01-2020-statement-onthe-second-meeting-of-the-international-health-regulations(2005)-emergency-committee-regarding-the-outbreak-of-novelcoronavirus-(2019-ncov).

3. "WHO Director-General's opening remarks at the media briefing on COVID-19". World Health Organization (WHO) (Press release), 11 March 2020. Archived from the original on 11 March 2020. Available from: https://www.who.int/dg/speeches/detail/whodirector-general-s-opening-remarks-at-the-media-briefing-oncovid-19---11-march-202.

4. В России выявили двух первых больных коронавирусом. Доступно по ссылке: https://www.interfax.ru/russia/693554.

5. COVID-19 Dashboard by the Center for Systems Science and Engineering (CSSE) at Johns Hopkins University (JHU). Available from: https://gisanddata.maps.arcgis.com/apps/opsdashboard/ index.html\#/bda7594740fd40299423467b48e9ecf6.

6. Qiu J, Shen B, Zhao M, et al A nationwide survey of psychological distress among Chinese people in the COVID-19 epidemic: implications and policy recommendations. General Psychiatry. 2020; 33: e100213.

7. Brooks SK, Webster RK, Smith LE, Woodland L, Wessely S, Greenberg N, et al. The Psychological Impact of Quarantine and How To Reduce It: Rapid Review of the Evidence. The Lancet. 2020; 395 (10227): 912-20. Available from: https://doi.
org/10.1016/S0140-6736(20)30460-8.

8. Yao H, Chen JH, Xu YF. Patients with mental health disorders in the COVID-19 epidemic. Lancet Psychiatry. 2020; 7 (4): e21. DOI: 10.1016/S2215-0366(20)30090-0/.

9. Lai J, Ma S, Wang Y, Cai Z, Hu J, Wei N, et al. Factors Associated With Mental Health Outcomes Among Health Care Workers Exposed to Coronavirus Disease 2019. JAMA Netw Open. 2020; 3 (3): e203976. DOI: 10.1001/jamanetworkopen.2020.3976.

10. Addressing Stigma. Centers for disease control and prevention. Available from: https://emergency.cdc.gov/cerc/cerccorner/ article_123016.asp.

11. Водопьянова Н. Е. Психодиагностика стресса. СПб.: Питер, 2009; $336 \mathrm{c}$.

12. Link B, Cullen F, Frank J, Wozniak J. The Social Rejection of Former Mental Patients: Understanding Why Labels Matter. American Journal of Sociology. 1987; 92 (6): 1461-500. Retrieved April 12, 2020. Available from: www.jstor.org/stable/2779844.

13. Novel coronavirus (2019-nCoV): strategic preparedness and response plan Feb 3, 2020. World Health Organization, 2019 [cited 2020 Feb 7]. Available from: https://www.who.int/docs/ default-source/coronaviruse/srp-04022020.pdf.

14. Li W, Yang Y, Liu ZH, Zhao Y-J, Zhang Q, Zhang L, et al. Progression of Mental Health Services during the COVID-19 Outbreak in China. Int J Biol Sci. 2020; 16 (10): 1732-8. DOI: 10.7150/ijbs.45120.

15. Chen Q, Liang M, Li Y, Cuo J, Fei D, Wang L, et al. Mental health care for medical staff in China during the COVID-19 outbreak. Lancet Psychiatry. 2020; 7 (4): e15-e16. DOI: 10.1016/S22150366(20)30078-X.

16. Kang L, Li Y, Hu S, Chen M, Yang C, Yang BX, et al. The mental health of medical workers in Wuhan, China dealing with the 2019 novel coronavirus. Lancet Psychiatry. 2020; 7 (3): e14. DOI: 10.1016/S2215-0366(20)30047-X. 